\title{
Effects of innovation on the growth of ecuadorian firms: a quantile analysis
}

\author{
Luis Enrique Simbaña-Taipe \\ lesimbania@espe.edu.ec \\ University ESPE, Ecuador \\ David Rodeiro-Pazos \\ david.rodeiro@usc.es \\ University of Santiago de Compostela, Spain \\ María Jesús Rodríguez-Gulías \\ maria.gulias@udc.es \\ University of A Coruña, Spain \\ Sara Fernández-López \\ sara.fernandez.lopez@usc.es \\ University of Santiago de Compostela, Spain
}

\begin{abstract}
This paper analyzes the relationship between firms' innovation and growth measured by sales and labor productivity in Ecuador. The literature on this topic has focused mainly on developed countries. We apply panel data quantile regressions to analyze a sample of 99,872 private limited company and public limited company for the period 2000-2013. Quantile regression allows us to avoid conventional analysis through the study of the average impact for the average company, which can lead to the discovery of phenomena underlying relationships. The results show that firm innovation has a negative on productivity growth. In contrast, there is a positive relationship between innovation and sales growth for firms in some quantiles. These results lead us to establish a series of recommendations aimed at public policy decision-makers. In particular, the support of government entities is important for a company's R\&D activities, which contribute to generating profitable intangible assets. This support can be through advice, subsidies, or tax benefits, among others. At the country level, government effort to protect intangible assets is also important, promoting competitive advantages for those companies that actually invest or buy such assets.
\end{abstract}

Keywords: innovation, growth, quantile regressions, panel data, Ecuador. 
Rodeiro-Pazos, D., Simbaña-Taipe, L.E., Rodríguez-Gulías, M.J. \& Fernández-López, S. (2018) Effects of innovation on the growth of ecuadorian firms: a quantile analysis. Journal of Business, Universidad del Pacífico (Lima, Peru) Vol.10(2): 70-87

\section{Introduction}

In recent times an increasing number of studies have analyzed the determinants of business growth. Within the growing literature, a large number of studies point to innovation as a key factor in favoring growth and generating significant returns for companies (Cainelli et al., 2006; Coad, 2009; Goedhuys \& Sleuwaegen, 2010; Coad \& Rao, 2011 and Choi et al., 2016). In turn, other researchers have struggled to find that innovation has a significant effect on company growth, as in the case of Bottazzi et al. (2001) and Corsino and Gabriele (2011). And there are others still who point to negative effects, such as Evangelista and Savona (2003) and Yasuda (2005).

An important aspect in which most of the abovementioned works coincide, regardless of their results, is that investing in R\&D is a high-risk activity (Coad and Rao, 2008) and does not guarantee success or returns through significant economic performance.

In developed countries, research, science and technologies are considered key factors in strengthening the competitiveness of the economy. A large part of the studies carried out in such countries have stressed that far from being an optional strategy, innovation is fundamental for achieving high-level growth, especially for small and medium-sized enterprises (Van Roy and Nepelski, 2016). Thus, the public administrations of these countries usually allocate funds to this type of activities (Salazar et al., 2013).

On the other hand, developing countries, especially those of Latin America, are more austere in their level of R\&D investment compared to their developed counterparts. In the case of Ecuador, levels of R\&D expenditure as a percentage of GDP are lower than the average for Latin America and the Caribbean, surpassing only Colombia within the region (Schwartz and Guaipatin, 2014).

In this study we analyze the impact of innovation, measured through intangible assets, on the sales growth and labor productivity of Ecuadorian companies. To this end, we use a sample of 25,976 companies over the period 2000-2013. We apply quantile regression for panel data, to establish whether there is an effect and, if so, whether it varies depending on the position occupied by the company in the distribution of growth rates. This study includes some characteristics that help to identify the contribution of innovation. First, it is a pioneering analysis of growth in Ecuador and among the few conducted to date in Latin America. In this way, we cover a gap in the literature, which has mainly focused on developed countries. Second, the number of companies we use represents almost public limited companies and private limited companies in Ecuador.

Third, we use a long period of study (14 years). Fourth, we capture labor productivity as a measure of non-recurrent growth in the literature, as well as innovation represented by intangible assets as an explanatory variable, which complements the results of previous works. Finally, in terms of methodology, we employ quantile regression, following Canay (2011). This methodology allows us to avoid conventional analysis through the study of the average impact for the average company, which can lead to the discovery of phenomena underlying relationships.

This document is structured as follows: section 2 reviews the literature; in section 3 we provide a description of the data and variables used as well as the estimation strategy; in section 4 we present the results of the empirical analysis; and finally, in section 5 we present the main conclusions, as well as the limitations and future lines of research. 
Rodeiro-Pazos, D., Simbaña-Taipe, L.E., Rodríguez-Gulías, M.J. \& Fernández-López, S. (2018) Effects of innovation on the growth of ecuadorian firms: a quantile analysis. Journal of Business, Universidad del Pacífico (Lima, Peru) Vol.10(2): 70-87

\section{Literature review}

Within the literature there is a broad set of theories and approaches to studying company growth, but they do not reach a consensus regarding its measurement and the factors that motivate it. Most works agree that it is a highly complex heterogeneous process with individual characteristics, involving different ways of combining resources and strategies (Federico and Capelleras, 2015).

Within these theoretical and empirical studies, innovation has been a recurring factor when it comes to justifying business growth, and is considered the cornerstone of productivity gains and economic growth (Dosi, 2009). And Delmar et al. (2003) state that company growth can originate through innovation and dissemination of new products and processes.

Innovative activity can increase the chances of survival and subsequent growth of a company (Calvo, 2006). In these circumstances, the role of innovation becomes the force that ensures the way to compete and the success of future activities (Herrera, 2009).

The use of innovation strategy is generally associated with investments in R\&D, contributing to the generation of intangible assets in a company. Del Monte and Papagni (2003) highlight that intensity of research is positively related to intensity of innovation. On the other hand, Hall (1986) argues that companies that invest in R\&D, regardless of their size, will have greater possibilities for growth. His study uses a stochastic approach to growth, based on the contributions of Gibrat (1931) and the logic of size-age in a dynamic context and environment. Along the same lines, Adamou and Sasidharan (2007) find that R\&D has a significant impact on company growth.

In addition, the strategies implemented by companies are influenced by the type of assets they own. In this case, intangible assets have a remarkable importance, because their increase contributes to diversifying productive activities and the product portfolio, which enables a higher rate of growth (Hall, 1986). Similarly, Serrasqueiro et al., (2010) argue that small and medium-sized enterprises with a greater number of intangible assets manifest greater adaptability with which to take advantage of productive opportunities, in the form of innovation strategies that can contribute to significant increases in company growth.

In line with the previous theoretical arguments, many empirical studies have found a positive relationship between innovation and company growth, particularly when this is measured through sales (Coad 2009; Goedhuys and Sleuwaegen 2010; Choi et al., 2016). These results point to innovation as one of the main drivers of company performance and growth (Mansfield, 1962; Almus \& Nerlinger, 1999; Autio et al., 2007; Coad \& Rao 2010; Brenner \& Schimke, 2015).

However, some studies have had difficulty identifying any clear impact of innovation on the growth of companies. Corsino and Gabriele (2011) find that innovation in general do not make a significant impact. Likewise, Bottazzi et al. (2001), when analyzing the 
Rodeiro-Pazos, D., Simbaña-Taipe, L.E., Rodríguez-Gulías, M.J. \& Fernández-López, S. (2018) Effects of innovation on the growth of ecuadorian firms: a quantile analysis. Journal of Business, Universidad del Pacífico (Lima, Peru) Vol.10(2): 70-87

dynamics of the pharmaceutical sector, do not discover any significant relationship between R\&D innovation and company growth.

Moreover, some works, such as that of Yasuda (2005), establish that there is a negative relationship between growth and expenditure on R\&D, especially in the first years of life of a company, because investment of this type is related to a higher risk index. Investing in R\&D is a risky activity even if some kind of competitive advantage is generated. Therefore, companies must find the right balance between investment, the form of production, and marketing if they are to appropriate some percentage of the returns.

On the other hand, the intensity of innovation, measured as the relationship between innovation expenses and billing, is used by Elche and González (2008) to analyze Spanish service companies, allowing them to classify companies in two dimensions: high and low intensity of innovation. They determine that high intensity has a significant impact on performance, as well as proactivity towards innovation and internal promotion; and that, in the case of low intensity, high levels of profitability are not necessarily related to innovation strategy.

For their part, Coad and Rao (2008) study innovation intensity by dividing R\&D values by sales for US companies over the period 1963-2002, finding that this variable has a significant impact on high-growth companies. Similarly, Del Monte and Papagni (2003), when analyzing Italian companies for the period 1989-1997; and Lee (2009), using data from the World Bank, establish that the effect of the innovation intensity on the growth of companies varies according to the sector, and can positively influence the growth rate of a company. Meanwhile, Coad et al., (2016) using the variable intensity of R\&D by dividing investment in R\&D by the number of employees, determine that of Spanish companies in the period 2004-2012, those in the lower quantiles have a negative relationship with the growth of sales and productivity, while those in the higher quantiles have a positive relationship.

The fact that there are no unanimous findings regarding the growth-innovation relationship can be explained by several factors. These range from the different ways of measuring the company innovation, to the time that a company needs to obtain economic returns through such innovation (Coad and Rao, 2008). In fact, one of the main difficulties experienced by companies that employ an innovation strategy is that it can take a long time to observe improved economic performance, given that once innovation has been achieved, companies have to invest considerable resources in the development of the product and its placement in the market.

Recently, a strand of the literature has pointed out that the methodology used to relate innovation and growth has focused on the "average company". However, the innovation process can have different effects depending on the position of the company in the distribution of growth rates. Indeed, this distribution tends to have a "carp shape" for which quantile regression techniques seem most appropriate (Bianchini et al., 2015; Coad et al., 2016; Nogueira et al., forthcoming). Table 1 shows the works that have used these techniques, as well as the main results obtained. 
Rodeiro-Pazos, D., Simbaña-Taipe, L.E., Rodríguez-Gulías, M.J. \& Fernández-López, S. (2018) Effects of innovation on the growth of ecuadorian firms: a quantile analysis. Journal of Business, Universidad del Pacífico (Lima, Peru) Vol.10(2): 70-87

Table 1: Studies on the effect of innovation on the growth of companies (quantile regression)

\begin{tabular}{|c|c|c|c|c|c|}
\hline Author & Country & Period & $\begin{array}{c}\text { Sample } \\
\text { (companies) }\end{array}$ & Dependent & Results \\
\hline \multirow{4}{*}{$\begin{array}{l}\text { Nogueira et } \\
\text { (forthcoming) }\end{array}$} & \multirow{4}{*}{ Spain } & \multirow{4}{*}{ 2004-2014 } & \multirow{4}{*}{$\begin{array}{l}80 \text { listed } \\
\text { companies }\end{array}$} & \multirow{4}{*}{ Sales } & $\begin{array}{c}(-)<=\text { quantile } 50 \\
\text { Patents }\end{array}$ \\
\hline & & & & & (+) R\&D expenses \\
\hline & & & & & $\begin{array}{c}\text { (-) R\&D intangible } \\
\text { asset }\end{array}$ \\
\hline & & & & & $\begin{array}{c}(+)>\text { quantile } 90 \\
\text { Intensity of industrial } \\
\text { property }\end{array}$ \\
\hline \multirow{4}{*}{ Coad et al. (2016) } & \multirow{4}{*}{ Spain } & \multirow{4}{*}{ 2004-2012 } & \multirow{4}{*}{26,600} & \multirow{2}{*}{ Sales } & $(-)<=$ quantile 50 \\
\hline & & & & & $(+)>$ quantile 50 \\
\hline & & & & \multirow{2}{*}{$\begin{array}{l}\text { Productivit } \\
\text { y }\end{array}$} & $(-)<=$ quantile 10 \\
\hline & & & & & $(+)>$ quantile 10 \\
\hline Bianchini et al. (2015) & Spain & 2004-2011 & 5,064 & Sales & $(+)$ \\
\hline $\begin{array}{l}\text { Demirel and Mazzucato } \\
(2010)\end{array}$ & United States & $1950-2008$ & 256 & Sales & $(+)$ \\
\hline \multirow{2}{*}{ Navaretti et al. (2014) } & \multirow{2}{*}{$\begin{array}{l}\text { Italy, France, } \\
\text { Spain }\end{array}$} & \multirow{2}{*}{ 2001-2008 } & \multirow{2}{*}{38,806} & \multirow{2}{*}{$\begin{array}{l}\text { Employme } \\
\text { nt }\end{array}$} & $\begin{array}{c}(-)>=\text { quantile } 90 \\
\text { (product) }\end{array}$ \\
\hline & & & & & $\begin{array}{c}(+)<\text { quantile } 90 \\
\text { (product) }\end{array}$ \\
\hline \multirow{2}{*}{$\begin{array}{l}\text { Serrasqueiro } \\
\text { (2010) }\end{array}$} & \multirow{2}{*}{ Portugal } & \multirow{2}{*}{ 1998-2006 } & \multirow{2}{*}{39} & \multirow{2}{*}{ Total assets - } & $(+)>=$ quantile 90 \\
\hline & & & & & $(-)<$ quantile 90 \\
\hline Capasso et. Al. (2015) & Netherlands & $1996-2011$ & 13,236 & $\begin{array}{l}\text { Employme } \\
\mathrm{nt}\end{array}$ & $(+)$ \\
\hline $\begin{array}{l}\begin{array}{l}\text { Mazzucato and Parris } \\
(2015)\end{array} \\
\end{array}$ & United States & 1963-2002 & 370 & Sales & $(+)$ \\
\hline $\begin{array}{lll}\begin{array}{l}\text { Segarra } \\
(2014)\end{array} & \text { and } & \text { Teruel } \\
\end{array}$ & Spain & 2004-2008 & 3,807 & $\begin{array}{l}\text { Employme } \\
\text { nt and Sales }\end{array}$ & $(+)$ \\
\hline Colombelli et al. (2013) & France & $1992-2004$ & 1,074 & Sales & $(+)$ \\
\hline $\begin{array}{l}\text { Czarnitzki and Delanote } \\
(2013)\end{array}$ & Belgium & 2001-2008 & 3,537 & Sales & $(+)$ \\
\hline Falk (2012) & Austria & $1995-2006$ & $620-830$ & $\begin{array}{l}\text { Employme } \\
\text { nt and Sales }\end{array}$ & $(+)$ \\
\hline Coad and Rao (2011) & United States & 1963-1968 & 1,920 & Employees & $(+)$ \\
\hline Coad and Rao (2008) & United States & $1963-2002$ & 4,395 & Sales & $(-)$ \\
\hline
\end{tabular}

Considering the previous theoretical basis and the problems identified in the literature, we propose the following hypotheses to relate innovation intensity and company growth of the company.

Hypothesis 1: There is a positive relationship between innovation intensity and company growth.

Hypothesis 2: The relationship between innovation intensity and company growth is less intense for companies with less growth. 
Rodeiro-Pazos, D., Simbaña-Taipe, L.E., Rodríguez-Gulías, M.J. \& Fernández-López, S. (2018) Effects of innovation on the growth of ecuadorian firms: a quantile analysis. Journal of Business, Universidad del Pacífico (Lima, Peru) Vol.10(2): 70-87

\section{Methodology}

In this section, we describe the sample and the variables used, as well as the estimation strategy and the econometric specification of the model.

\section{Sample and data}

In this study, we use the database of the Superintendence of Companies of Ecuador for the period 2000-2013, which collects information corresponding to the financial statements, which companies are required to submit each year. From the original database of 99,872 companies, during the first phase of data filtering we excluded those that did not have the requisite legal structure (public limited company or private limited company) as well as microenterprises. Then, we eliminated companies with values that did not correspond to the nature of the calculation (Table 2).

Table 2: Sample construction

\begin{tabular}{lcc} 
Criteria & \multicolumn{1}{c}{$\begin{array}{c}\text { No. of } \\
\text { companies } \\
\text { eliminated }\end{array}$} & $\begin{array}{c}\text { No. of companies } \\
\text { in the sample }\end{array}$ \\
\hline \begin{tabular}{l} 
Initial database \\
\hline $\begin{array}{l}\text { Exclusion of companies other than public and private } \\
\text { limited companies }\end{array}$
\end{tabular} & 110 & 99,872 \\
\hline $\begin{array}{l}\text { Exclusion of microenterprises } \\
\text { Exclusion of companies that do not meet the criteria of } \\
\text { minimum social capital for their corporate structure }\end{array}$ & 1,287 & 41,363 \\
\hline $\begin{array}{l}\text { Values that do not correspond to the nature of the } \\
\text { calculation }\end{array}$ & 15,357 & 25,976 \\
\hline Final database & & 25,976 \\
\hline
\end{tabular}

The final sample is made up of an unbalanced panel of 25,976 companies for the period 2000-2013.

\section{Definition and measurement of the variables}

Company growth is measured through the growth in sales and labor productivity (dependent variables). One of the most significant advantages of using sales as a measure of growth lies in its ability to represent the acceptance of the company's products/services by customers, thus indicating the activity and presence of the company in the market (Delmar et al., 2013).

For its part, labor productivity is one of the characteristics of growing companies (Baily et al., 1996), under the premise that natural selection progressively eliminates weak companies, thus generating an increase in the level of average productivity of the surviving companies (Coad et al., 2013).

The sales variable (VT) is represented by net annual sales, while the labor productivity variable (PRODCT) is the result of dividing net sales by the number of employees. 
Rodeiro-Pazos, D., Simbaña-Taipe, L.E., Rodríguez-Gulías, M.J. \& Fernández-López, S. (2018) Effects of innovation on the growth of ecuadorian firms: a quantile analysis. Journal of Business, Universidad del Pacífico (Lima, Peru) Vol.10(2): 70-87

The dependent variable is the natural logarithm of the annual growth rate, expressed as:

$$
\text { Growth }_{i, t}=\ln \left(S_{i, t}\right)-\ln \left(S_{i, t-1}\right)=\ln \left(\frac{S_{i, t}}{S_{i, t-1}}\right)
$$

Where $\mathrm{S}_{-}(\mathrm{i}, \mathrm{t})$ and $\mathrm{Si}, \mathrm{t}-1$ represent the volume of sales or labor productivity of the company $i$ in periods $t$ and $t-1$.

As a fundamental independent variable, we have selected the intensity of innovation (INTINNOV). For its construction, we start with the definition proposed by Coad et al., (2016), who use the natural logarithm of the result of dividing R\&D investments by sales. In our case, we will use intangible assets by sales, following Loi and Khan (2012), who indicate that this type of assets represents the level of innovation of a company.

Unlike Coad et al. (2016), given the reduced weight that these intangible assets hold over sales, we do not apply any logarithmic conversions. As explanatory variables, we use variables denoting specific characteristics of the company and financial performance, which, according to the traditional literature (Coad, 2009), can condition the growth of companies (Table 3).

Lee (2010) states that the specific characteristics of the industry, as well as those of each company, affect the business growth pattern. Within this group of variables, we have focused on those factors most commonly used by the literature, such as: previous growth, employment, age, technology, and sector (Brenner and Schimke, 2015). We measure previous growth by the natural logarithm of sales/labor productivity, delayed by one period (L1.LNVT / L1.LNPRODCT). This also includes the variable employment growth (G_EM), measured as the natural logarithm of the annual growth rate of the number of employees (Coad et al., 2016; Aissa and Goaied, 2016; Park \&Jang, 2010). We also use the natural logarithm of the age of the company (LNEDAD) (Jovanovic, 1982; Fariñas \& Moreno, 1997; Oliveira and Fortunato, 2006; Bigsten \& Gebreeyesus, 2007; Loi and Khan, 2012).

Additionally, we use the square of the age of the company (LNEDADCUAD), to verify the existence of non-linear relationships (Rodríguez et al., 2016). In order to determine the effect of the sector, we create a dummy that takes the value 1 if the company belongs to the industrial sector (IND), and 0 otherwise. Finally, we measure the technological level of the sector in which the company operates through a dummy variable that takes the value 1 when the company operates in a low technology sector (BAJA_TECH) and 0 otherwise.

Regarding financial performance, Hax and Majluf (1984) state that sustainable growth is represented by a company's use of its internal resources as well as its debt capacity, which can sustain that company's maximum growth. In particular, we define two variables of financial performance. The first is indebtedness (END), defined as a company's leverage factor, determined by dividing the total debt by the total assets. The second is capital growth (G_CAP), which is calculated as the natural logarithm of the annual growth rate of capital, which is included in order to control the company's entry factors (Coad et al., 2016; Aissa and Goaied, 2016; Park and Jang, 2010). 
Table 3: Definition of independent variables and expected sign

\begin{tabular}{|c|c|c|c|c|c|}
\hline Group & Factor & Variable & $\begin{array}{l}\text { Sales } \\
\text { Growth }\end{array}$ & $\begin{array}{l}\text { Productivity } \\
\text { Growth }\end{array}$ & Measure \\
\hline Innovation & Innovation & INTINNOV & + & + & $\begin{array}{l}\text { Intangible assets / } \\
\text { Sales }\end{array}$ \\
\hline \multirow{7}{*}{$\begin{array}{l}\text { Characteristics of } \\
\text { the company }\end{array}$} & \multirow{2}{*}{ Previous growth } & L1.LNVT & - & n.a. & \multirow{3}{*}{$\begin{array}{l}\text { Natural sales logarithm } \\
(\mathrm{t}-1) \\
\text { Natural logarithm of } \\
\text { labour productivity (t-1) } \\
\text { Natural logarithm of the } \\
\text { annual growth rate in the } \\
\text { number of employees }\end{array}$} \\
\hline & & L1.LNPRODCT & n.a. & - & \\
\hline & Employment & $G \_E M$ & + & - & \\
\hline & & LNAGE & - & - & Natural logarithm of age \\
\hline & Age & LNSQUAGE & + & + & $\begin{array}{l}\text { Natural logarithm of age } \\
\text { squared }\end{array}$ \\
\hline & Sector & IND & + & + & $\begin{array}{l}1 \text { if the company belongs } \\
\text { to the industrial sector } \\
\text { and } 0 \text { otherwise }\end{array}$ \\
\hline & $\begin{array}{l}\text { Technological } \\
\text { level of the sector }\end{array}$ & LOW_TECH & - & - & $\begin{array}{l}1 \text { if the company belongs } \\
\text { to a low technology } \\
\text { sector and } 0 \text { otherwise }\end{array}$ \\
\hline \multirow{2}{*}{$\begin{array}{l}\text { Financial } \\
\text { Performance }\end{array}$} & Capital & G_CAP & + & + & $\begin{array}{l}\text { Natural logarithm of the } \\
\text { annual rate of capital } \\
\text { growth }\end{array}$ \\
\hline & Indebtedness & END & + & + & $\begin{array}{l}\text { Total liabilities / total } \\
\text { assets }\end{array}$ \\
\hline
\end{tabular}

\section{Estimation strategy and model specification}

The studies on business growth and its relationship with innovation have used different methodologies for estimation, such as least squares with fixed effects (Serrasqueiro et al., 2010; Nogueira et al., Forthcoming), or the generalized method of moments (GMM) (Triguero and Córcoles, 2013). When using these estimation methods, these studies have focused on the average effect for the average company (Coad and Broekel, 2012). However, this approach can hide important characteristics of the underlying relationship. In particular, the optimal properties of standard regression estimators are not robust to small variations of a normal distribution. In contrast, quantile regressions are characteristically robust to outliers and heavy-tailed distributions. In addition, by not considering the limiting assumption that the terms of error are distributed identically throughout the distribution, quantile regressions allow recognition of a company's heterogeneity.

In order to estimate the effect by sections of the variables considered, we apply the quantile regression technique for panel data (Coad et al., 2016). This method, by not focusing on the average company, has the capacity to explain heterogeneous behaviors along the (conditional) distribution of the dependent variable. Also, this analysis is robust for analysis of atypical observations of the variable explained. Moreover, the quantile regression of panel data will control for the specific effects of the company that are invariant over time, in order to improve analysis of the effects of innovation intensity on company growth. 
Rodeiro-Pazos, D., Simbaña-Taipe, L.E., Rodríguez-Gulías, M.J. \& Fernández-López, S. (2018) Effects of innovation on the growth of ecuadorian firms: a quantile analysis. Journal of Business, Universidad del Pacífico (Lima, Peru) Vol.10(2): 70-87

The form of the equation we use is:

$G_{-} V T_{i, t}=\beta_{0}+\beta_{1} I N T I N N O V_{i t}+\beta_{2} L 1 . L N V T_{i t}+\beta_{3} G_{-} E M_{i t}+\beta_{4} L N E D A D_{i t}+$ $\beta_{5} L N E D A D C U A D_{i t}+\beta_{6} B A J A_{-} T E C H_{i}+\beta_{7} I N D_{i}+\beta_{8} E N D_{i t}+\beta_{9} G_{-} C A P_{i t}+$

$\mu_{t}+\varepsilon_{i t}$

$G_{-} P R D C_{i, t}=\beta_{0}+\beta_{1} I N T I N N O V_{i t}+\beta_{2}$ L1.LNPRODCT $i t+\beta_{3} G_{-} E_{i t}+$ $\beta_{4} L N E D A D_{i t}+\beta_{5} L N E D A D C U A D_{i t}+\beta_{6}$ BAJA_TECH $H_{i}+\beta_{7} I N D_{i}+\beta_{8} E N D_{i t}+$ $\beta_{9} G_{-} C A P_{i t}+\mu_{t}+\varepsilon_{i t}$

Where $Y_{-}(i, t)$ is the growth rate of the company; $\llbracket B \rrbracket+(j)$ are the coefficients of the explanatory variables; $\mu$ _t corresponds to the company-specific fixed effects invariant in time; and $\varepsilon_{-}$is the error term for company $i$ at time $t$. In our estimation, we use the quantile estimator of fixed effects (Canay, 2011), which operates in two stages.

In order to increase the precision of our inference, we use bootstrap (with 400 repetitions).

\section{Empirical results}

Univariate analysis

In this section, we begin by analyzing the distribution of our independent variables - that is, the annual growth rate in the logarithmic scale of sales, and labor productivity (Figure 1). The first thing to be noted is the characteristic "carp shape" and the distribution of the heavy tail growth rate, which denotes relatively high frequency in atypical events (Coad, 2009; Segarra \& Teruel, 2014; Navaretti et al., 2014;), and which also characterizes the sample of Ecuadorian companies. Consequently, using regressions of the median - that is, the minimization of least absolute deviations (LAD) instead of ordinary least squares (OLS), makes the quantile regression especially useful in the presence of atypical data, heterocedasticity, or structural change (Yrigoyen and Reyes, 2012).

Figure 1: Kernel density estimation of sales growth and labor productivity

\section{G_VT}

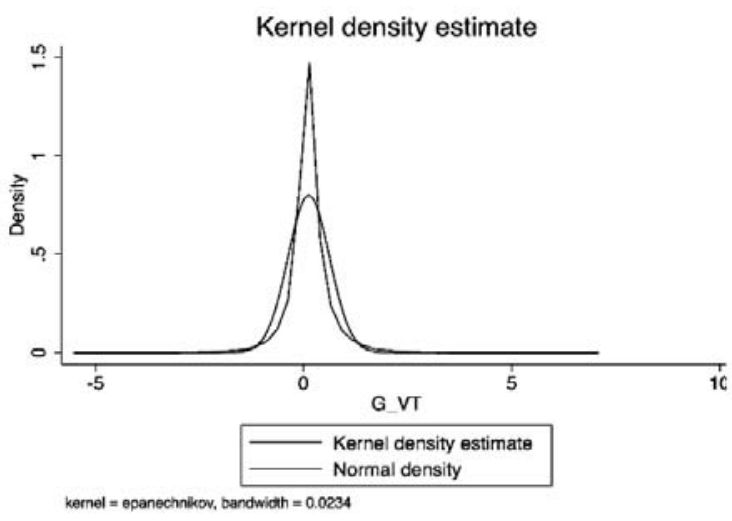

G_PRDC

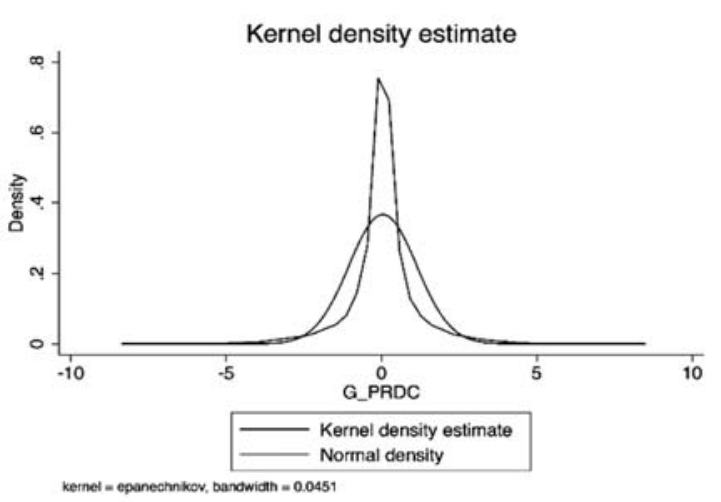


Rodeiro-Pazos, D., Simbaña-Taipe, L.E., Rodríguez-Gulías, M.J. \& Fernández-López, S. (2018) Effects of innovation on the growth of ecuadorian firms: a quantile analysis. Journal of Business, Universidad del Pacífico (Lima, Peru) Vol.10(2): 70-87

Table 4 shows the descriptive statistics for the explanatory variables. The average sales of the companies are 3,160,284 USD, the average number of employees is 33 , and the average index of productivity is 286,418 USD.

For its part, the innovation intensity of the Ecuadorian companies is not very high, since on average intangible assets represent $1 \%$ of sales.

The companies that belong to the industrial sector constitute $14 \%$ of the sample. In turn, $5 \%$ of the companies operate in sectors whose technological level is low. Finally, the level of indebtedness is $66 \%$, the average capital is 320,033 USD, and the average age is 12.5 years, while the maximum is 93 years.

Table 4: Descriptive statistics of explanatory variables

\begin{tabular}{llrrrrr}
\multicolumn{1}{c}{ Variable } & \multicolumn{1}{c}{ Description } & Obs. & Media & Std. Dev. & Min & Max \\
\hline VT & Sales & 204,905 & $3,160,284$ & $19,600,000$ & 100,002 & $1,750,000,000$ \\
\hline G_VT & Sales growth & 154,330 & 0.12 & 0.50 & -5.49 & 7 \\
\hline PRODCT & Labour productivity & 135,107 & $286,417,80$ & $3,258,903$ & 20.16 & $425,000,000$ \\
\hline G_PRDC & $\begin{array}{l}\text { Growth in labour } \\
\text { productivity }\end{array}$ & 89,285 & 0.04 & 1.09 & -8.30 & 0 \\
\hline EM & Employment & 152,268 & 32.95 & 156.99 & 0 & 13,679 \\
\hline G_EM & Employment Growth & 89,299 & 0.08 & 1.02 & $-8,04$ & 8 \\
\hline INTINNOV & Intensity of innovation & 106,774 & 0.01 & 0.25 & 0 & 1 \\
\hline AGE & Age & 204,923 & 12.50 & 10.83 & 0 & 49 \\
\hline LOW_TECH & Low technology & 204,358 & 0.05 & 0.22 & 0 & 93 \\
\hline IND & Belongs to the industry & 204,358 & 0.14 & 0.35 & 0 & 1 \\
\hline END & Indebtedness & 192,455 & 0.66 & 0.25 & 0 & 1 \\
\hline CAP & Capital & 204,908 & $320,033,10$ & $4,235,009$ & 400 & $522,000,000$ \\
\hline
\end{tabular}

There are no high or significant correlations between the growth measures (sales and labor productivity) and the explanatory variables.

\section{Multivariate analysis}

The results of the quantile regression are presented in Table 5 and Table 6 (sales and labor productivity, respectively). The defined estimator is based on the conditional quantile regression developed by Koenker and Hallock (2001) and Koenker (2004), where $q$ represents the quantile $(0>q<1)$ of the conditional distribution.

By focusing on the results of the estimation of the company's growth measured through sales, innovation intensity (INTINNOV) is shown to have a significant negative impact for the 0.25 quantile, a positive and significant impact for the 0.50 and 0.75 quantiles, and no significant relationship is for the quantiles 0.10 and 0.90 . Therefore, in the case of growth measured through sales, we can establish that there is a negative relationship 
between the innovation intensity and growth for companies that are in the lower quantiles and positive for companies that are in the higher quantiles, (Hypothesis 1), while the relationship is less intense for companies with lower growth (Hypothesis 2). This coincides in part with the results of Coad et al. (2016).

On the other hand, the results of the estimation of labor productivity growth show a negative relationship between innovation intensity and company growth in all the quantiles, thus rejecting Hypothesis 1 . However, in general, the negative sign of this relationship is more intense in the lower quantiles of the growth rate distribution, which allows Hypothesis 2 to be accepted. In this case, innovation intensity seems to exert a negative effect on the growth of labor productivity, regardless of the growth quantile in which the company is located. These results coincide with those of Nogueira et al. (forthcoming).

With regard to the variables related to the characteristics of the company, previous growth (L1.LNVT) exerts a negative effect on the growth of sales, except for the quantiles 0.10 and 0.90 , where this effect is not significant. These results imply that small businesses tend to grow in sales, rather than large ones, thus rejecting Gibrat's Law, as occurs in much of the empirical work. On the other hand, the effect is positive for all the quantiles in the case of growth in labor productivity (L1.LNPRODCT).

Thus, the most efficient companies would tend to increase their efficiency even more in the subsequent years.

Meanwhile, growth in employment (G_EM), as expected, presents a negative relationship for growth in labor productivity, regardless of the quantile in which the company is located.

Age (LNAGE and LNSQUAGE) maintains a negative relationship with growth in sales for those companies that are in the higher quantiles $(<75)$. This result is consistent with the general evidence that high-growth companies tend to be young companies (Moreno and Coad, 2015). On the other hand, when we talk about growth in productivity, the relationship with age adopts a U-ratio, regardless of the quantile in which the company is located. That is, in the beginning a company's growth in productivity would decrease, until it reaches a certain age, when it would begin to increase. This relationship fits with the theories of learning proposed by Jovanovic (1982).

Finally, belonging to an industrial sector (IND) generally has a positive effect on the growth of a company, both in terms of sales and labor productivity; these results correspond with Segarra and Teruel (2014). Conversely, operating in low technology sectors (LOW_TECH) has a negative impact on both types of growth, with some exceptions.

As regards the variables related to financial performance, capital growth (G_CAP) seems to have a positive effect on business growth in low quantiles $(<0.25)$; however, this effect is reversed in some of the high quantiles $(0.25$ and 0.75 for sales and $>0.90$ for labor productivity). These results indicate that a greater contribution of own resources could have a negative impact on the growth of a company when it is positioned at high growth rates. Perhaps this increased contribution of resources serves to "relax" a company's incentives to continue growing at a significant rate. 
As to indebtedness (END), this is usually positively related to productivity growth.

This result is consistent with the arguments of Meyer (1998), who proposes that debt is fundamental for companies, because it helps to discipline managers so that they do not invest in projects that cause the company to grow beyond the optimum level, which would negatively influence the value of the company. On the other hand, Serrasqueiro et al. (2010) argue that companies with a high level of indebtedness tend to use resources efficiently, because they have to pay the debt periodically.

Table 5: Quantile regression of the growth variable measured through sales

\begin{tabular}{|c|c|c|c|c|c|}
\hline Variable & QR_10 & QR_25 & QR_50 & QR_75 & QR_90 \\
\hline \multirow[t]{2}{*}{ INTINNOV } & $-0,661$ & $-0.118 * * *$ & $0.102 * * *$ & $0.074 * * *$ & $-0,085$ \\
\hline & $(0,433)$ & $(0,004)$ & $(0,012)$ & $(0,006)$ & $(0,053)$ \\
\hline \multirow[t]{2}{*}{ L1.LNVT } & $-0,071$ & $-0.010^{*}$ & $-0.040 * * *$ & $-0.070 * * *$ & $-0,045$ \\
\hline & $(0,063)$ & $(0,004)$ & $(0,003)$ & $(0,003)$ & $(0,027)$ \\
\hline \multirow[t]{2}{*}{ G_EM } & 0,051 & $0.021 * * *$ & $-0.008 * *$ & $-0,004$ & $-0,029$ \\
\hline & $(0,039)$ & $(0,005)$ & $(0,003)$ & $(0,003)$ & $(0,046)$ \\
\hline \multirow[t]{2}{*}{ LNAGE } & $-0,694$ & $-0,043$ & $-0,085$ & $-0.218 * * *$ & $-0.463^{*}$ \\
\hline & $(0,491)$ & $(0,025)$ & $(0,053)$ & $(0,045)$ & $(0,215)$ \\
\hline \multirow[t]{2}{*}{ LNSQUAGE } & 0,13 & $0.010^{*}$ & $0.020 *$ & $0.048 * * *$ & 0,05 \\
\hline & $(0,085)$ & $(0,004)$ & $(0,01)$ & $(0,008)$ & $(0,042)$ \\
\hline \multirow[t]{2}{*}{ LOW_TECH } & 1,108 & $-0.178 * * *$ & $-0.786 * * *$ & $-1.603^{* * *}$ & $-2.403 * * *$ \\
\hline & $(1,237)$ & $(0,026)$ & $(0,1)$ & $(0,099)$ & $(0,466)$ \\
\hline \multirow[t]{2}{*}{ IND } & $-0,038$ & $0.071 * * *$ & $0.364 * * *$ & $0.626 * * *$ & $0.554 * * *$ \\
\hline & $(0,199)$ & $(0,016)$ & $(0,031)$ & $(0,048)$ & $(0,098)$ \\
\hline \multirow[t]{2}{*}{ END } & 0,404 & $0.071 * *$ & $-0.100 * * *$ & $-0,003$ & $-0.344^{*}$ \\
\hline & $(0,422)$ & $(0,022)$ & $(0,013)$ & $(0,007)$ & $(0,172)$ \\
\hline \multirow[t]{2}{*}{ G_CAP } & $-0,126$ & $0.004^{*}$ & $-0.023 * * *$ & $-0.019 * * *$ & $-0,042$ \\
\hline & $(0,138)$ & $(0,002)$ & $(0,006)$ & $(0,002)$ & $(0,028)$ \\
\hline $\mathrm{N}$ & & & 24659 & & \\
\hline
\end{tabular}

Notes: ${ }^{*} p<.05 ;{ }^{* *} p<.01 ;{ }^{* * *} p<.001$. The regression includes a complete set of annual dummies 
Table 6: Quantile regression of the growth variable measured through labor productivity

\begin{tabular}{|c|c|c|c|c|c|}
\hline Variable & QR_10 & QR_25 & QR_50 & QR_75 & QR_90 \\
\hline \multirow[t]{2}{*}{ INTINNOV } & $-0.120 * * *$ & $-0.166^{* * *}$ & $-0,047$ & $-0.080 * * *$ & $-0.093 * * *$ \\
\hline & $(0,019)$ & $(0,029)$ & $(0,026)$ & $(0,009)$ & $(0,006)$ \\
\hline \multirow[t]{2}{*}{ L1.LNPRODCT } & $0.055^{* * *}$ & $0.074^{* *}$ & $0.035^{* * *}$ & $0.072^{* * *}$ & $0.110^{* * *}$ \\
\hline & $(0,002)$ & $(0,026)$ & $(0,002)$ & $(0,011)$ & $(0,002)$ \\
\hline \multirow[t]{2}{*}{ G_EM } & $-0.944 * * *$ & $-0.950 * * *$ & $-0.972 * * *$ & $-0.932 * * *$ & $-0.898 * * *$ \\
\hline & $(0,003)$ & $(0,011)$ & $(0,003)$ & $(0,007)$ & $(0,004)$ \\
\hline \multirow[t]{2}{*}{ LNAGE } & $-0.192^{* * *}$ & $-0.324 * * *$ & $-0.197 * * *$ & $-0.549 * * *$ & $-0.704^{* * *}$ \\
\hline & $(0,026)$ & $(0,098)$ & $(0,02)$ & $(0,052)$ & $(0,009)$ \\
\hline \multirow[t]{2}{*}{ LNEDADCUAD } & $0.044^{* * *}$ & $0.055^{* * *}$ & $0.027 * * *$ & $0.080^{* * *}$ & $0.105^{* * *}$ \\
\hline & $(0,005)$ & $(0,015)$ & $(0,004)$ & $(0,01)$ & $(0,002)$ \\
\hline \multirow[t]{2}{*}{ LOW_TECH } & $0.049 * *$ & 0,307 & $-0.206^{*}$ & $-0.239 * * *$ & $-0.221 * * *$ \\
\hline & $(0,016)$ & $(0,204)$ & $(0,084)$ & $(0,058)$ & $(0,014)$ \\
\hline \multirow[t]{2}{*}{ IND } & $0.076^{* * *}$ & $-0,047$ & $0.082^{* * *}$ & $0.078^{* * *}$ & $0.072^{* * *}$ \\
\hline & $(0,01)$ & $(0,067)$ & $(0,019)$ & $(0,009)$ & $(0,012)$ \\
\hline \multirow[t]{2}{*}{ END } & $0.127^{* * *}$ & $0.158^{*}$ & 0,019 & $-0,004$ & $0.152^{* * *}$ \\
\hline & $(0,035)$ & $(0,07)$ & $(0,018)$ & $(0,068)$ & $(0,011)$ \\
\hline \multirow[t]{2}{*}{ G_CAP } & $0.013^{* *}$ & $0.014 *$ & $-0,003$ & 0,002 & $-0.007 * *$ \\
\hline & $(0,004)$ & $(0,007)$ & $(0,007)$ & $(0,007)$ & $(0,003)$ \\
\hline $\mathrm{N}$ & & & 24659 & & \\
\hline
\end{tabular}

\section{Conclusions}

In modern economic thinking, innovation is attributed an important role in business growth, since companies that invest in innovation more than their competitors can increase their chances of success. However, companies that take the risk of investing in research and development must combine invention, production know-how, and marketing if they are to succeed in their objectives and generate the desired performance. Therefore, innovative companies can achieve extraordinary success or lose significant resources, which reveals that innovation is uncertain and companies generally lack persistence in its application.

Many previous studies have analyzed these interrelationships in companies in developed countries, but they may differ from those of their counterparts in developing countries.

The results obtained from the relationship between innovation intensity and company growth are mixed. Thus, when referring to sales growth, it can be established that innovation intensity has greater impact for companies with higher growth, and the opposite for companies with lower growth. In turn, measuring growth by labor productivity shows that innovation intensity has a negative impact on both companies with higher growth and lower growth. 
These results suggest that investments in intangible assets can reduce the sales of companies with low growth and boost those of companies that experience higher growth. On the other hand, when referring to the growth in labor productivity, innovation intensity has a negative impact. This may be due to inadequate innovation management, characterized by a lack of a balance between invention, the mode of production and the marketing strategy. Another possible explanation for our results can be derived from the economic and market conditions in Ecuador, which do not allow innovation to become, at least in the short term, a sustainable competitive advantage. As an example, the index of intellectual property rights, which measures the extent to which the a country's laws protect intellectual property rights, gave Ecuador a score of 4.8 in 2016, positioning the country in 12th place in the region (out of 22 countries) and 81st in the world (out of 121 countries) (Levy-Carciente, 2016). Therefore, investing in R\&D that can be easily imitated by competitors may be reducing companies' productivity growth.

In addition to the innovation intensity, other variables have a clear effect on business growth. Thus, past growth has a negative effect on sales, but a positive one on labor productivity, confirming that for Ecuador, Gibrat's Law is not fulfilled and that the most efficient companies in terms of labor productivity maintain certain persistence over time. This growth in labor productivity has a negative relationship with growth in employment. On the other hand, age tends to negatively affect the companies with the highest growth in sales, while maintaining a non-linear relationship with labor productivity. Taken together, both results together indicate that, after going through "adolescence", companies grow less in sales and more in labor productivity - something that, as we have defined in the variables, implies that they sacrifice employment.

In addition, the sector in which a company operates also has an influence. In general, industrial sectors tend to favor growth, while those of low intensity in the use of technology harm it, regardless of whether sales or labor productivity are analyzed.

On the other hand, the results corresponding to the financial performance variables, taken as a whole, confirm the arguments that arise from financial agency theory; the fact of a company financing itself to a greater extent with debt tends to discipline management by making the operations of that company more efficient. Meanwhile, the behavior of capital growth varies.

Even though previous theoretical and empirical studies have tried to explain the impact of innovation on business growth, be it through R\&D expenditures or patents, few have analyzed the influence of innovation represented by intangible assets. Our results show that in the case of sales growth rate, the effect of innovation intensity increases through the quantiles from negative to positive. Meanwhile, the impact of this variable is negative on the growth rate of labor productivity, which means that innovation may be associated with employment growth.

These results and their implications lead us to establish a series of recommendations aimed at those who formulate public policies. Given that the intensity of innovation favors the sales growth of those companies with high growth rates, the support of government entities to the companies' R\&D activities are important for contributing to generating profitable intangible assets. This support can be through advice, subsidies, or tax benefits, among others. At the country level, government efforts to protect these intangible assets are also important, helping to generate competitive advantages for those companies that actually invest or buy such intangible assets. This, undoubtedly, would attract more foreign investors, able to see possibilities of innovation in Ecuadorian companies. In turn, public policies should take into account the age of the company. In other words, it is necessary to design different support policies depending on the stage in which each company is located. 
Rodeiro-Pazos, D., Simbaña-Taipe, L.E., Rodríguez-Gulías, M.J. \& Fernández-López, S. (2018) Effects of innovation on the growth of ecuadorian firms: a quantile analysis. Journal of Business, Universidad del Pacífico (Lima, Peru) Vol.10(2): 70-87

Among the limitations of this research, the analysis focuses exclusively on firms with a certain corporate structure (public limited company or private limited company). Future research should repeat the analysis for large companies, with the aim of seeing whether there are differences in the dynamics of growth. In addition, the database from which we start does not allow for distinctions within intangible assets, which partly corresponds to patents, trademarks or other intangible assets.

In any case, we believe that our results may be useful to understand what happens in the growth process of companies in other countries that, similar to Ecuador, are in the process of development.

\section{References}

Adamou, A. and Sasidharan, S. (2007). The impact of R\&D and FDI on firm growth in emerging-developing countries: Evidence from Indian manufacturing industries. Available at SSRN: https://ssrn.com/abstract=987024.

Aissa, S.B. and Goaied, M. (2016). Determinants of Tunisian hotel profitability: The role of managerial efficiency, Tourism Management, Vol. 52, pp. 478-487.

Almus, M. and Nerlinger, E.A. (1999). Growth of new technology-based firms: which factors matter?, Small business economics, Vol. 13, No.2, pp. 141-154.

Autio, E., Kronlund, M. and Kovalainen, A. (2007). High-growth SME Support Initiatives in Nine Countries: Analysis, Categorization, and Recommendations: Report Prepared for the Finnish Ministry of Trade and Industry. Ministry of Trade and Industry.

Baily, M.N., Bartelsman, E.J. and Haltiwanger, J. (1996). Downsizing and productivity growth: myth or reality?, Small Business Economics, Vol. 8, No.4, pp. 259-278.

Bigsten, A. and Gebreeyesus, M. (2007). The small, the young, and the productive: Determinants of manufacturing firm growth in Ethiopia, Economic Development and Cultural Change, Vol. 55, No.4, pp. 813-840.

Bottazzi, G., Dosi, G., Lippi, M., Pammolli, F. and Riccaboni, M. (2001). Innovation and corporate growth in the evolution of the drug industry, International Journal of Industrial Organization, Vol. 19, No.7, pp. 1161-1187.

Brenner, T. and Schimke, A. (2015). Growth Development Paths of Firms-A Study of Smaller Businesses, Journal of Small Business Management, Vol. 53, No.2, pp. 539557.

Cainelli, G., Evangelista, R. and Savona, M. (2006). Innovation and economic performance in services: a firm-level analysis, Cambridge Journal of Economics, Vol. 30 , No.3, pp. 435-458.

Calvo, J.L. (2006). Testing Gibrat's law for small, young and innovating firms, Small Business Economics, Vol. 26, No.2, pp. 117-123.

Canay, I.A. (2011). A simple approach to quantile regression for panel data, The Econometrics Journal, Vol. 14, No.3, pp. 368-386.

Choi, K.S., Lee, J.D. and Baek, C. (2016). Growth of De Alio and De Novo firms in the new and renewable energy industry, Industry and Innovation, Vol. 23, No.4, pp. 295312.

Coad, A. (2009), The growth of firms: A survey of theories and empirical evidence. Edward Elgar Publishing.

Coad, A. and Broekel, T. (2012). Firm growth and productivity growth: evidence from a panel VAR, Applied Economics, Vol. 44, No.10, pp. 1251-1269. 
Rodeiro-Pazos, D., Simbaña-Taipe, L.E., Rodríguez-Gulías, M.J. \& Fernández-López, S. (2018) Effects of innovation on the growth of ecuadorian firms: a quantile analysis. Journal of Business, Universidad del Pacífico (Lima, Peru) Vol.10(2): 70-87

Coad, A. and Rao, R. (2008) Innovation and firm growth in high-tech sectors: A quantile regression approach, Research policy, Vol. 37, No.4, pp. 633-648.

Coad, A. and Rao, R. (2010). Firm growth and R\&D expenditure", Economics of Innovation and New Technology, Vol. 19, No.2, pp. 127-145.

Coad, A. and Rao, R. (2011). The firm-level employment effects of innovations in hightech US manufacturing industries, Journal of Evolutionary Economics, Vol. 21, No.2, pp. 255-283.

Coad, A., Segarra, A. and Teruel, M. (2013). Like milk or wine: Does firm performance improve with age?, Structural Change and Economic Dynamics, Vol. 24, pp. 173-189.

Coad, A., Segarra, A. and Teruel, M. (2016). Innovation and firm growth: Does firm age play a role?, Research Policy, Vol. 45, No.2, pp. 387-400.

Corsino, M. and Gabriele, R. (2010). Product innovation and firm growth: evidence from the integrated circuit industry, Industrial and corporate change, p. dtq050.

Del Monte, A. and Papagni, E. (2003). R\&D and the growth of firms: empirical analysis of a panel of Italian firms, Research policy, Vol. 32, No.6, pp. 1003-1014.

Delmar, F., Davidsson, P. and Gartner, W.B. (2003). Arriving at the high-growth firm, Journal of business venturing, Vol. 18, No.2, pp. 189-216.

Delmar, F., McKelvie, A. and Wennberg, K. (2013). Untangling the relationships among growth, profitability and survival in new firms, Technovation, Vol. 33, No.8, pp. 276-291.

Del Monte, A., \& Papagni, E. (2003). R\&D and the growth of firms: empirical analysis of a panel of Italian firms. Research policy, 32(6), 1003-1014.

Demir, R., Wennberg, K. and McKelvie, A. (2016). The strategic management of highgrowth firms: a review and theoretical conceptualization, Long Range Planning.

Dosi, G. (1982). Technological paradigms and technological trajectories: a suggested interpretation of the determinants and directions of technical change, Research policy, Vol. 11, No.3, pp. 147-162.

Elche, D. M., \& González, Á. (2008). Influence of innovation on performance: analysis of Spanish service firms. The Service Industries Journal, 28(10), 1483-1499.

Evangelista, R. and Savona, M. (2003), Innovation, employment and skills in services. Firm and sectoral evidence, Structural Change and Economic Dynamics, Vol. 14, No.4, pp. 449-474.

Fariñas, J.C. and Moreno, L. (1997), Size, Age and Growth: An Application to. Fundación Empresa Pública.

Federico, J.S. and Capelleras, J.L. (2015). The heterogeneous dynamics between growth and profits: the case of young firms, Small Business Economics, Vol. 44, No.2, pp. 231-253.

Gibrat, R. (1931), Les inégalités économiques. Recueil Sirey.

Global Innovation Index (2017). Global Report, http://www. wipo.int/publications/es/details. jsp?id=4193

Goedhuys, M. and Sleuwaegen, L. (2010). High-growth entrepreneurial firms in Africa: a quantile regression approach, Small Business Economics, Vol. 34, No.1, pp. 31-51.

Hall, B.H. (1986). The relationship between firm size and firm growth in the US manufacturing sector. National Bureau of Economic Research Cambridge, Mass., USA.

Hax, A.C. and Majluf, N.S. (1984). Strategic management: an integrative perspective. 
Rodeiro-Pazos, D., Simbaña-Taipe, L.E., Rodríguez-Gulías, M.J. \& Fernández-López, S. (2018) Effects of innovation on the growth of ecuadorian firms: a quantile analysis. Journal of Business, Universidad del Pacífico (Lima, Peru) Vol.10(2): 70-87

Herrera, G. (2009). La innovación como estrategia y solución empresarial para impulsar la competitividad y un crecimiento sostenido a largo plazo, Ciencia y Mar, Vol. 13, No.38, pp. 51-60.

Jovanovic, B. (1982). Selection and the Evolution of Industry, Econometrica: Journal of the Econometric Society, pp. 649-670.

Koenker, R. (2004). Quantile regression for longitudinal data, Journal of Multivariate Analysis, Vol. 91, No.1, pp. 74-89.

Koenker, R. and Hallock, K. (2001). Quantile regression: An introduction, Journal of Economic Perspectives, Vol. 15, No.4, pp. 43-56.

Lee, C. Y. (2009). Competition favors the prepared firm: Firms' R\&D responses to competitive market pressure. Research Policy, 38(5), 861-870.

Lee, C.Y. (2010), A theory of firm growth: Learning capability, knowledge threshold, and patterns of growth, Research Policy, Vol. 39, No.2, pp. 278-289.

Lee, N. (2014). What holds back high-growth firms? Evidence from UK SMEs, Small Business Economics, Vol. 43, No.1, pp. 183-195.

Levy-Carciente, D. (2016). International property rights index. Washington, DC: Property Rights Alliance.

Loi, T.H. and Khan, A.A. (2012). Determinants of firm growth: evidence from Belgian companies, Master thesis, university of GENT.

Mansfield, E. (1962). Entry, Gibrat's law, innovation, and the growth of firms, The American economic review, pp. 1023-1051.

Meyer, L.H. (1998). The present and future roles of banks in small business finance, Journal of Banking \& Finance, Vol. 22, No.6, pp. 1109-1116.

Moreno, F. and Coad, A. (2015). High-growth firms: Stylized facts and conflicting results, en Entrepreneurial Growth: Individual, Firm, and Region, Emerald Group Publishing Limited, pp. 187-230.

Navaretti, G.B., Castellani, D. and Pieri, F. (2014). Age and firm growth: evidence from three European countries, Small Business Economics, Vol. 43, No. 4, pp. 823-837.

Nogueira, A., Fernández-López, S., Rodríguez-Gulías, M.J., Vivel-Búa, M. and RodeiroPazos, D. (forthcoming): The hidden effect of innovation in the growth of the Spanish firms, International Journal of Entrepreneurship and Small Business.

Oliveira, B. and Fortunato, A. (2006). Firm growth and liquidity constraints: A dynamic analysis, Small Business Economics, Vol. 27, No.2-3, pp. 139-156.

Park, K. and Jang, S.S. (2010). Firm growth patterns: examining the associations with firm size and internationalization, International Journal of Hospitality Management, Vol. 29, No.3, pp. 368-377.

Rodríguez-Gulías, M.J., Fernández-López, S. and Rodeiro-Pazos, D. (2016). Growth determinants in entrepreneurship: A longitudinal study of Spanish technology-based university spin-offs, Journal of International Entrepreneurship, Vol. 14, No.3, pp. 323344.

Roy, V.V. and Nepelski, D. (2016). Assessment of Framework Conditions for the Creation and Growth of Firms in Europe, Joint Research Centre (Seville site), Working Paper JRC103350.

Salazar, M. and Valderrama, M.G. (2013). La Alianza Universidad-Empresa-Estado: una estrategia para promover innovación, Revista EAN, No.68, pp. 112-133. 
Schwartz, L. y Guaipatín, C. (2014). Ecuador: Análisis del Sistema Nacional de Innovación: Hacia la consolidación de una cultura innovadora. https://publications.iadb.org/handle/11319/6664

Segarra, A. and Teruel, M. (2014). High-growth firms and innovation: an empirical analysis for Spanish firms, Small Business Economics, Vol. 43, No.4, pp. 805-821.

Serrasqueiro, Z., Nunes, P. M., Leitão, J., \& Armada, M. (2010). Are there non-linearities between SME growth and its determinants? A quantile approach. Industrial and Corporate Change, 19(4), 1071-1108.

Triguero, Á. and Córcoles, D. (2013). Understanding innovation: An analysis of persistence for Spanish manufacturing firms, Research Policy, Vol. 42, No.2, pp. 340352.

Yasuda, T. (2005). Firm Growth, Size, Age and Behavior in Japanese Manufacturing, Small Bus Econ, Vol. 24, No.1, pp. 1-15.

Yrigoyen, C.C. and Reyes, B.S. (2012). Externalidades Ambientais e Prezo Da Vivenda En Madrid: Unha Análise Con Regresión Cuantílica Espacial, Revista Galega de Economía. Vol. 21, No. 2, pp. 277-296. 